Journal Universitas Muhammadiyah Gresik Engineering, Social Science, and Health International Conference (UMGESHIC)

UMGCINMATIC : $1^{\text {st }}$ Rethinking Education during Covid-19 Era: Challange and Innovation

\title{
ANALYSIS OF CHANGES IN HAND WASHING TECHNIQUES IN PRESCHOOL CHILDREN THROUGH THE DEMONSTRATION METHOD
}

\author{
Author \\ Diah Fauzia Zuhroh ${ }^{1}$, Wiwik Widiyawati ${ }^{2}$, Nurul Hidayatul Jannah ${ }^{3}$ \\ Lecturer of Health Faculty, Universitas Muhammadiyah Gresik ${ }^{\mathbf{1}}$, Lecturer of Health \\ Faculty, Universitas Muhammadiyah Gresik ${ }^{2}$, Student of Health Faculty, Universitas \\ Muhammadiyah Gresik ${ }^{3}$
}

\begin{abstract}
fauzia_diah@umg.ac.id ${ }^{1}$, wiwikwidiyawati@umg.ac.id ${ }^{2}$, jannahnurul762@gmail.com ${ }^{3}$
\end{abstract}

\begin{abstract}
Prevention of the spread of Covid-19 does not only need to be done in the affected areas., nursing mothers and even children and infants (Zukmadini, A.Y., Karyadi, B., \& Kasrina, 2020). It can be a risk of wider transmission of COVID-19 if people cannot maintain and preserve good habits, one of which is washing hands. Preschoolers are a phase where they are able to imitate well. Teach preschool children how to wash hands properly and correctly so that it can be done every day. The demonstration method is expected to form the right attitude in hand washing techniques in preschool children. This type of research is pre-experimental with a cross sectional approach. The variable studied was hand washing technique. Data collection uses observation sheets and is obtained periodically. The number of samples in the study was 79 preschool students in the Bangkalan area. The data was processed using the Friedman test. The results showed that before health education was given, most of the hand washing techniques in children had less criteria as many as $79(100 \%)$ children. Furthermore, the mean in the 1st and 2 nd interventions was 1 , the 3 rd intervention was 1.05 , and the 4 th intervention was 2.54 . From the results of statistical tests using the Friedman test, a p value of 0.000 was obtained ( $p$ $<0.05)$. Changes in attitude began with the 3rd and 4th interventions regarding hand washing techniques through demonstration method health education for pre-school children.
\end{abstract}

Keyword : Covid-19, hand washing, preschool

\section{INTRODUCTION}

Until September 11, 2020, positive cases of Covid-19 in the world reached 28.3 million people with a recovery rate of 19 million people and 911 thousand people died (Aida, 2020). The COVID-19 pandemic has been going on for 7 months in Indonesia. Currently, the condition of the spread of the virus is increasing, even Indonesia is the country with the highest number of cases of Covid-19 infection. Positive cases of Covid-19 in Indonesia reached 210,940 people with a recovery rate of 150,217 people and 8,544 people died (Pradipta, 2020). 
The impact is wider, apart from education, the economy and relations between countries are at their lowest point.

Bangkalan Regency is one of the districts with the second-highest number of residents who have tested positive for COVID-19 on the island of Madura, the total number of Bangkalan residents who have tested positive for Covid-19 is 1,482 people, 1,116 people recovered, and 133 people died (Dinkes, 2020). Covid-19 can enter through the triangular areas of the face, such as the eyes, nose, and mouth which are parts that are easily touched by the hands, consciously or unconsciously. According to WHO, the prevention of transmission of COVID-19 is by keeping a distance, wearing a mask, and washing hands. Washing hands with soap and running water is an effective way to clean germs, bacteria, and viruses. Allegedly there are still many people who wash their hands using only water. Even though washing hands using only water cannot remove germs and bacteria that stick to the hands (Ministry of Health, 2020).

Basic Human Services (BHS) states that in Indonesia in 2006 only $12 \%$ washed their hands after defecating, $14 \%$ before eating, $9 \%$ after washing children, and 6\% before preparing food. The 2013 Basic Health Research (Riskesdas) stated that the proportion of age 10 years who washed their hands properly was only $46.7 \%$. The Directorate General of Disease Control and Environmental Health of the Indonesian Ministry of Health (2013) stated that only $18.5 \%$ of Indonesians wash their hands with soap at five important times. The frequency of children washing their hands incorrectly is $56 \%$, while according to National Data, according to the Health Service Program Survey, there are 15\% who do not wash their hands properly. Data in East Java shows that $23.7 \%$ of children wash their hands incorrectly (Andriawan, 2014). These results indicate that the technique of washing hands in children is still not done well.

The handwashing technique is cleaning hands with soap and clean running or splashed water, usually used before and after taking actions that do not have a risk of disease transmission (Depkes, 2011). Correct handwashing techniques need to be taught to children from an early age and must become a habit. There are several ways to teach children about hand washing techniques properly, one of which is by giving a direct demonstration of how to wash hands. The demonstration method can also help children in developing handwashing skills so that children become accustomed to washing their hands (Depkes, 2011). So this study aims to analyze how handwashing techniques in preschool children are given after being given a demonstration method intervention in Bangkalan.

\section{METHODS}

This type of research is experimental observational with a cross-sectional approach. Conducted during January-March 2021. Data collection was taken by observing 96 children. The data was obtained using the Friedman statistical test analysis.

\section{RESULT AND DISCUSSION}

The research was conducted in East Jaddih Village, Socah District, 8 km from Bangkalan 
City. The majority of the population adheres to Islam. The residents' livelihoods are farmers and workers outside the area. The results of the study were obtained from 79 preschool children as follows:

a. Age Gender

\section{CHILD's AGE}


4 tahun

- 5 tahun

6 tahun

b. Child Gender

\section{CHILD GENDER}
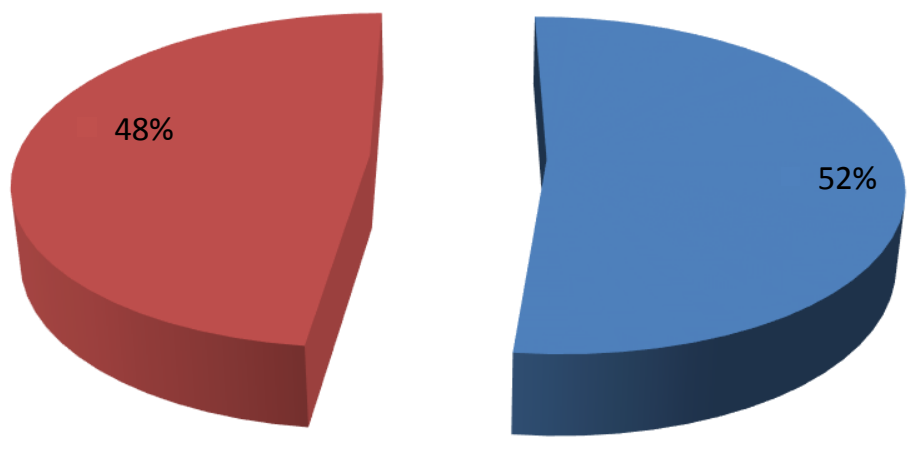

- Perempuan

- Laki-laki

c. Change analysis 
UMGCINMATIC : $1^{\text {st }}$ Rethinking Education during Covid-19 Era: Challange and Innovation Volume 1 No 2

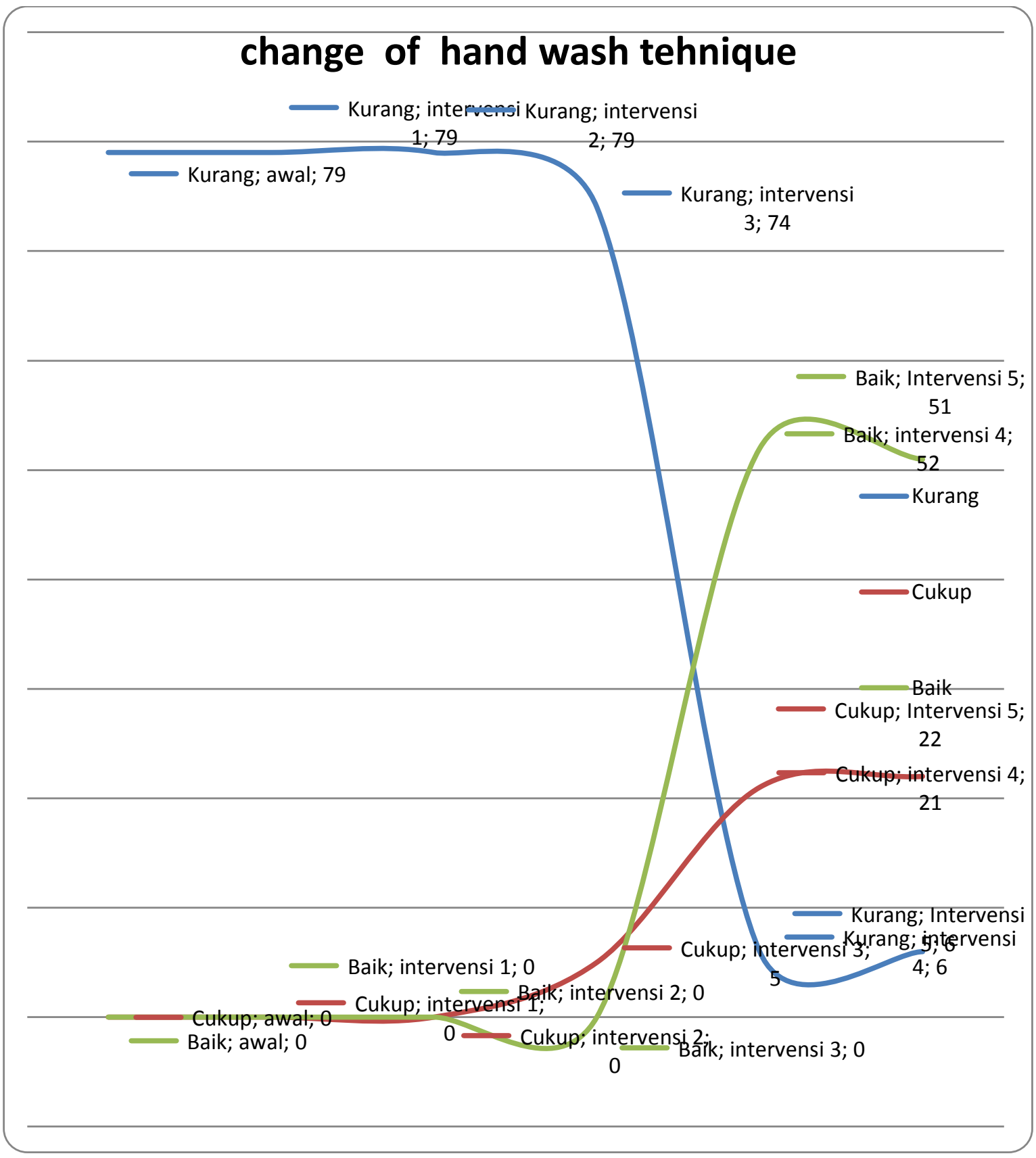

\section{Hypothesis Test Summary}

Null Hypothesis

Test

Sig.

Decision

\begin{tabular}{ll|l}
\hline 1 & The distributions of & Related-Samples
\end{tabular}

awal, interv_1, interv_2, Friedman's Two-Way

.000 Reject the null

hypothesis.

interv_3, interv_4, and Analysis of Variance by

interv 5 are the same. Ranks

Asymptotic significances are displayed. The significance level is .050. 
The results of the statistical test showed a significant change in handwashing techniques in preschool children in Bangkalan after receiving 5 interventions in washing hands.

Based on the existing phenomena, it can be seen that preschool-age children have a habit of not paying attention to the need for handwashing in everyday life, especially in the school environment. They usually eat the food they buy around the school without washing their hands first, whereas before they were playing. This behavior is certainly influential and can contribute to the occurrence of diarrheal disease. Hand washing is the most important basic technique in preventing and controlling infection transmission (Sastima, Nur Ridha, 2017).

Based on the initial results of the study, none of the children were correct in doing the handwashing technique. The level of knowledge of children's handwashing techniques before being given health education in the demonstration group was in the less category. The majority of children do not know about the impact of not washing their hands, when to wash their hands, and how to wash their hands properly and correctly. All children have never received health education about hand washing before. This is in accordance with the statement from the principal that so far, no health education has been held in schools except for information about handwashing which was conveyed by the teacher orally in the middle of the learning process so that children lacked information regarding hand washing. The lack of facilities and infrastructure, in this case, is good, and correct hand washing health education can affect the level of knowledge of children who are lacking (Green, 2011).

All of the children have not been able to carry out the act of washing their fingertips properly, where the respondent does not put the fingertips into the palm of the hand but rubs the figure irregularly in the act of washing the fingertips, then the respondent's ability also looks low on the indicator of washing the fingertips and thumb with a twisting action and unable to perform the hand drying technique properly. Another lowest ability is in the act of distributing soap with both palms until it foams and rubbing between the fingers, namely as much handwashing behavior is an activity carried out in cleaning the palms, backs of the hands, and fingers so that they are clean from dirt and kill germs that cause diseases that are detrimental to health. Humans and make hands smell good (Sastima, 2017).

Most of the children were female as many as 41 children (51.9\%). Female students are more cooperative in participating in health education and in the practice of washing hands with soap. Girls are easier to manage, when doing the pre-test girls line up neatly, in contrast to boys who wash their hands carelessly (Bararah VF, 2012). In girls, hearing is more sensitive and the verbal center in the brain develops more quickly, so it can respond better. Research conducted by Prajawati, Triharini, and Asmoro revealed that girls in carrying out fine motor tasks are more skilled than boys. (Prajawati et al., 2014).

According to the researcher's assumptions, before the intervention in providing health promotion, it was known that overall respondents, namely pre-school children, were unable to carry out the 6 steps of handwashing correctly, where most of the respondents were unable to perform actions ranging from distributing soap with their hands to foaming, unable to perform the act of washing hands in the step of washing between the fingers, the tips of the fingers, the act of washing the thumbs and the act of drying hands with a towel properly. Where respondents wash their hands only with irregular rubbing movements so that they are not able to reach every 
gap between the sidelines and fingertips which causes the actions taken by respondents to be unable to clean their hands as a whole.

This condition occurs due to the respondent's ignorance of the proper handwashing technique, namely handwashing with 6 steps so that the handwashing action taken by the respondent is not appropriate and seems careless. In accordance with their developmental stage, pre-school children are children aged 4-6 years and at this stage, children tend to be active, show behavior, and like to play. This can also be seen in the act of washing hands which is the object and focus of this research, where when washing hands, it appears that children do it with enthusiasm but without the right steps and children tend to wash their hands according to their wishes, namely washing with irregular rubbing movements. according to their own wishes.

According to Notoatmodjo (2012), behavior is a form of response or reaction to a stimulus or stimulus from outside the organism (person), but in responding it is very dependent on the characteristics or other factors of the person concerned. Meanwhile, according to Notoatmodjo (2012), the factors that influence behavior include external factors and internal factors. The internal factors that influence behavior are the level of intelligence, emotional level, and gender. External factors that influence the environment, whether the physical environment, social, cultural, economic, or political. This environmental factor is the dominant factor that colors a person's behavior. The low handwashing behavior in preschool children in Jaddih Timur Kindergarten is due to many influencing factors such as environmental factors which are considered the most dominant factors that influence a person's behavior. Social environmental factors such as lack of socialization or lack of external stimulus about the correct way of handwashing techniques that make hand washing techniques are still low.

Based on the research, it appears that there is a good change after being given counseling with a demonstration method on handwashing techniques in preschool children. According to Green, health education is a conscious and planned effort, which is combined with learning experiences to improve a person's health behavior. The demonstration method is a method of presenting lessons by demonstrating and showing students about a certain process, situation, or object, either actual or just an imitation (Green, 2011). In this study, health education is one form of the implementation of School Health Nursing in the aspect of health promotion. The provision of this information is expected to increase children's knowledge of handwashing techniques.

According to Setiawan and Dermawan, health education is a series of efforts aimed at influencing other people, ranging from individuals, groups, families, and communities to the implementation of a healthy life (Setiawan, 2010). The intervention given is the provision of health promotion with the demonstration method. After the intervention, it was found that $59.5 \%$ of respondents had good criteria in carrying out 6 steps of handwashing and $25.3 \%$ of respondents still had sufficient criteria in carrying out 6 steps of handwashing. After the intervention, it was found that overall the children were able to perform the actions of rubbing the palms properly, washing the backs of the hands properly, washing between the fingers properly, and washing the tips and thumbs properly.

Based on the results of the study, before the demonstration method health education was given, most of the handwashing techniques in children with fewer criteria were 79 children (100\%), while after being given health education demonstration methods with good criteria were 47 
children (59.5\%). From the results of statistical tests using the Friedman test, $p$ value of 0.000 was obtained $(\mathrm{p}<0.05)$, which means that there is an effect of demonstration method health education on preschool children in Bangkalan.

Several studies have shown that there is a relationship between the level of knowledge of handwashing techniques before and after being given health education with demonstration methods (Andriani et al., 2014) regarding the title The Effect of Health Education With Audio Visual on Handwashing Behavior with Soap for Pre-School Children, the results showed that overall $(100 \%)$ respondents showed good handwashing behavior with soap. Overall, there is a significant relationship between knowledge from less to good with a $\mathrm{p}$ value of 0.000 .

Based on the results of the study, there were significant changes between intervention 3 and intervention4. Health education in this study used the demonstration method. The demonstration method is a method of presenting lessons by demonstrating and showing students about a certain process, situation, or object, either actual or just an imitation. Apart from the method of presentation, it cannot be separated from the teacher's explanation. Even though in the demonstration method students just pay attention. In the demonstration method, the process of student acceptance of the lesson will be more memorable in-depth, to form a perfect understanding. Also, students can observe the teacher during the learning process. The use of the demonstration method has the aim that students can understand how to organize or arrange something. During the demonstration in front of the class to wash hands with soap, the children were active and participated. The role of the media in learning, especially the education of preschoolers is increasingly important because children's thinking is based on what they see, hear or experience. Children's thinking at that age is at a time where they think concretely and real (Prajawati et al., 2014).

Measurements after being given the intervention were 5 times within 1 month. If it is too short, it is assumed that the respondent still remembers the material in the first measurement before health education so that they tend to repeat the same thing at the time of the next measurement. This is supported by the organism's stimulus theory explaining that behavioral changes can be produced by continuous stimulation of the individual. So that this demonstration method can be one of the learning options for preschool children in shaping behavior, for example how to wash hands properly and correctly.

The formation of handwashing behavior is the influence of the health education demonstration method. Through demonstration activities, many educational messages can be conveyed to children. Thus, knowledge and skills of healthy living behavior can be conveyed to children through demonstration activities. Through demonstration activities, especially if carried out jointly between educators and children, a pleasant atmosphere will be created, so that the message conveyed by educators is easily absorbed by children. So the demonstration method can be used in developing healthy living behavior in early childhood (Ismaniar, 2010). Health education about proper handwashing techniques is very much needed by preschoolers to improve optimal health degrees. The successful implementation of health education about handwashing techniques requires good cooperation between nurses or researchers, respondents, teachers, and parents of the children themselves. 


\section{CONCLUSIONS AND SUGGESTIONS}

a. Conclusions

Based on the research statement and the results of data analysis obtained during research activities, it can be concluded that Hand washing technique in preschool children before being given health education demonstration method (pre-test) in Jaddih Village, Socah District, Bangkalan Regency, most of the children had less criteria, namely 79 children (100\%). Hand washing technique in preschool children after being given health education demonstration method (post-test) in Jaddih Village, Socah District, Bangkalan Regency, most of the children had good criteria, namely 47 children $(59.5 \%)$. There is an effect of hand washing technique in preschool children on health education demonstration method in Jaddih Village, Socah District, Bangkalan Regency. There is a significant difference in each stage given the demonstration method of handwashing techniques to preschool children in Bangkalan. So it is hoped that this activity can be continued continuously to foster good habits in children in the face of the new normal era. There is a significant difference in each stage given the demonstration method of handwashing techniques to preschool children in Bangkalan. So it is hoped that this activity can be continued continuously to foster good habits in children in the face of the new normal era.

\section{Suggestions}

a. It is hoped that this researcher can be a reference for further researchers in developing research for health education demonstration methods, not only demonstration methods but in other methods.

b. For further researchers, they can modify or compare using other interventions to be more efficient in conducting health education demonstration methods.

c. The results of this study can be used as a reference for related institutions, one of which is Kindergarten in East Jaddih Village, Socah District, Bangkalan Regency, among others, Nurul Anwar Kindergarten, RA An-nidhomiyah, Salafiyah Safiiyah Kindergarten which is expected to add information in nursing science about health education counseling demonstration methods about proper hand washing techniques in preschool children.

d. Increase knowledge and insight regarding the effect of demonstration method health education on hand washing techniques in preschool children aged 4-6 years.

e. It is hoped that from the results of this study, children in Jaddih Village, Socah District, Bangkalan Regency can apply hand washing techniques at home independently in order to improve clean and healthy living behavior.

f. It is hoped that this researcher can be a reference for further researchers in developing research for health education demonstration methods, not only demonstration methods but in other methods.

g. For further researchers, they can modify or compare using other interventions to be more efficient in conducting health education demonstration methods.

\section{REFERENCES}

Abdul, H. (2018). Perilaku Hidup Bersih Dan Sehat ( Phbs ) Dengan Pada Balita Study Di Rw 
03 Desa Candimulyo Jombang. Skripsi

Fisik, P., Psikososial, D. A. N., Masa, P., \& Tahun, K. A. (2017). Perkembangan Fisik, Kognitif, Dan Psikososial Pada Masa Kanak-Kanak Awal 2-6 Tahun. Perkembangan Fisik, Kognitif, Dan Psikososial Pada Masa Kanak-Kanak Awal 2-6 Tahun, Iii(1), 19-33. Https://Jurnal.Ar-Raniry.Ac.Id/Index.Php/Bunayya/Article/Download/2042/1513

Hastuti, E. P., Aisah, S., \& Santosa, B. (2011). Hubungan Peran Orang Tua Dengan Kebiasaan Mencuci Tangan Pada Anak Prasekolah Di Taman Kanak-Kanak Siwi Peni Guntur Demak. Fikkes Jurnal Keperawatan, 4(2), 106-120.

Hurlock, E. (2013). Perkembangan Anak Jilid 1. Erlangga.

Lindawati. (2013). Faktor-Faktor Yang Berhungan Dengan Perkembangan Motorik Anak.

Maguwoharjo, H. B., \& Dini, A. U. (2019). Perkembangan Fisik Motorik Anak Usia Dini ( Standar Tingkat Pencapaian Perkembangan Anak) Stppa Tercapai Di Ra. 2(2), 112-136.

Mustikawati, I. S. (2017). Perilaku Cuci Tangan Pakai Sabun Studi Kualitatif Pada Ibu-Ibu Di

Kampung Nelayan Muara Angke Jakarta Utara; Studi Kualitatif. Arkesmas (Arsip

Kesehatan Masyarakat), 2(1), 115-125. Https://Doi.Org/10.22236/Arkesmas.V2i1.514

Notoatmodjo. (2012a). Metodologi Penelitian Kesehatan. Rineka Cipta.

Notoatmodjo, Soekidjo. (2012b). Promosi Kesehatan Dal Ilmu Perilaku. Rineka Cipta.

Nursalam. (2015). Metodologi Penelitian Ilmu Keperawatan Pendekatan Praktis.

Parasyanti, N. K. V., Yanti, N. L. G. P., \& Mastini, I. G. A. A. P. (2020). Pendidikan Kesehatan Cuci Tangan Pakai Sabun Dengan Video Terhadap Kemampuan Cuci Tangan Pada Siswa $\begin{array}{lllll}\text { Sd. Jurnal Akademika Baiturrahim Jambi, } & 9(1), & \end{array}$ Https://Doi.Org/10.36565/Jab.V9i1.197

Suprapto, R., Hayati, M., Nurbaity, S., Anggraeni, F., Haritsatama, S., Sadida, T. Q., Firoh, A., \& Pratama, F. A. (2020). Pembiasaan Cuci Tangan Yang Baik Dan Benar Pada Siswa Taman Kanak-Kanak (Tk) Di Semarang. Jurnal Surya Masyarakat, 2(2), 139. Https://Doi.Org/10.26714/Jsm.2.2.2020.139-145

Sutjiningsih. (2012). Tumbuh Kembang Anak. Buku Kedokteran EGC.

Welsh, J. A., Et Al. (2011). Development Of Cognitive Skills And Gains In Academic School Readiness For Children From Low-Income Families. 43-53.

Zukmadini, A.Y., Karyadi, B., \& Kasrina, K. (2020). Edukasi Perilaku Hidup Bersih Dan Sehat (Phbs) Dalam Pencegahan Covid-19 Kepada Anak-Anak Di Panti Asuhan. 